\title{
Corrosion Behavior of Reinforcement Steel Embedded in Cement Mortars Using Different Protection Systems
}

\author{
Evgenia Voulgari $^{1}$, Aggeliki Zacharopoulou ${ }^{1}$, Nikolaos Chousidis $^{2}$, George Batis ${ }^{1}$ \\ ${ }^{1}$ Department of Chemical Engineering, National Technical University of Athens, Athens, Greece \\ ${ }^{2}$ Department of Civil and Environmental Engineering, University of Cyprus, Nicosia, Cyprus \\ Email: voulgariep@gmail.vom, azachar@chemeng.ntua.gr, chousidis.nikolaos@ucy.ac.cy, batis@chemeng.ntua.gr
}

How to cite this paper: Voulgari, E., Zacharopoulou, A., Chousidis, N. and Batis, G. (2019) Corrosion Behavior of Reinforcement Steel Embedded in Cement Mortars Using Different Protection Systems. Materials Sciences and Applications, 10, 461-474. https://doi.org/10.4236/msa.2019.106034

Received: April 12, 2019

Accepted: June 17, 2019

Published: June 20, 2019

Copyright ( 2019 by author(s) and Scientific Research Publishing Inc. This work is licensed under the Creative Commons Attribution International License (CC BY 4.0). http://creativecommons.org/licenses/by/4.0/

\begin{abstract}
Although reinforced concrete structures are able to withstand towards a variety of adverse environmental conditions, reinforcement corrosion could lead to concrete structure deterioration. The present study examines four different ways of using corrosion inhibitors against pitting corrosion. In particular, it was investigated the chloride penetration resistance of reinforced cement mortars using corrosion inhibitor applied in three different ways. The corrosion behavior of the specimens was evaluated by electrochemical methods such as Linear Polarization Resistance and Half-cell Potential Resistance. In addition, the mass loss of steel rebars against time of partially immersion in sodium chloride $(\mathrm{NaCl})$ solution was carried out in the lab. The experimental results showed that the corrosion systems examined in the study provide anticorrosion protection on steel rebars against chlorides comparing with the reference group.
\end{abstract}

\section{Keywords}

Cement Mortars, Reinforcement Steel, Pitting Corrosion, Corrosion

Inhibitors, Chloride Ions, Electrochemical Measurements, Mass Loss

\section{Introduction}

Reinforced concrete structures facing a widespread premature deterioration, especially structures located in the coastal marine environment, due to corrosion of steel reinforcement [1].

Steel reinforcement in an uncracked concrete is protected due to the high alkalinity of the pore solution ( $\mathrm{pH}=12.5-13.5)$ [2]. A thin surface layer of hy- 
drated iron oxide is created upon the reinforcement protects reinforcement steel from corrosion.

Exposure of the reinforced concrete in a corrosive environment such as chloride ions $\left(\mathrm{Cl}^{-}\right)$or carbon dioxide $\left(\mathrm{CO}_{2}\right)$, may cause a decomposition/cracking of the passive film upon the steel surface and the corrosion of the steel reinforcement [3].

Chloride attack is one of the major reasons for the steel reinforcement corrosion which threatens concrete structures. Very high levels of chlorides can accumulate in concrete, particularly in marine structures. Chloride ions penetrate the concrete cover over the steel rebars and they can reach their surface [4], but the mechanism is not fully understood as the event occurs inside the concrete and the film is too thin to be examined. Chloride ions' intrusion depends of the porosity and permeability of concrete. The presence of chloride ions stimulates corrosion by raising the $p H$ required to stabilize the passive film to a value which may exceed that of a saturated calcium hydroxide solution [5].

When the ratio $\left[\mathrm{Cl}^{-}\right] /\left[\mathrm{OH}^{-}\right]$is bigger than 0.6 , chloride ions may penetrate concrete cover and build up over time until the concentration reaches a level sufficient to depassivate the steel [2]. After initiation of the corrosion process, the steel will begin corroding and setting up expansive stresses that will crack and spall the concrete cover [1] [6] which eventually result in progressive deterioration of the concrete.

The most widely protective methods for the effective protection of the steel reinforcement in concrete structures, are the following: cathodic protection, organic coatings, corrosion inhibitors-mineral additives such as pozzolans, silica fume etc. [7]. Corrosion inhibitors are organic or inorganic salts used as admixtures in concrete production in order to protect the steel rebars from the corrosion; on the other hand, the inhibitors improve the chloride penetration resistance of concrete. A corrosion inhibitor can be defined [8] as "a chemical compound" added in adequate amounts to concrete prevents or delays the corrosion of embedded steel and has no adverse effect on its physical/mechanical properties. It is worth noting that these types of admixtures increase the consistency of the passive layer on the steel surface, creating a barrier film on the steel, blocking the ingress of chlorides and increasing the degree of chloride binding capacity of the concrete; the oxygen ingress can be also prevented using the corrosion inhibitors or blocking the ingress of oxygen.

The advantages of using the inhibitors are that admixture is uniformly distributed throughout the concrete and therefore all the steel is equally protected and the use of admixture in concrete structures is not skill dependent as the correct amount of the admixture is only important [9]. It should be also mentioned that the corrosion inhibitors do not block the evolution of the corrosion process, but they rather increase the time of the onset of corrosion and reduce its eventual rate [10]. The fact that corrosion inhibitors may not remain in the repair area, or that there is a potential for micro-cell corrosion development when they are used in a limited area long a continuous reinforcing bar, are some of the drawbacks of 
corrosion inhibiting admixtures.

In previous work [11], it has been proved that the organic coatings can also be used for the protection of the steel reinforcement, as they consist a barrier between the porous concrete structure and the corrosive environment and so they are widely used in concrete structures for corrosion protection.

The main objective of this approach is the experimental study of different utilization of corrosion inhibitors. The possibility of protection that a corrosion inhibitor can provide, either as an additive or as a spray. Additionally, it was examined the protection that provides on the reinforcement steel an organic coating that contains corrosion inhibitor. The use of such organic coating would reduce the cost of labor as a single job will be required.

In order to determine the degree of protection of the corrosion inhibitor by different application modes (additive, spray, in color) specimens with reinforced mortar were made with four modes of inhibitor application were applied. These samples were exposed to a corrosive environment of $3.5 \%$ by weight and the degree of protection was evaluated by electrochemical measurements and by mass loss.

\section{Experimental}

Five groups of cylindrical specimens were constructed and each one of them consisted of 3 specimens. Each test probe was $10 \times 10 \times 10 \mathrm{~cm}$ in size and had 4 reinforcements, one in each corner with a $2 \mathrm{~cm}$ distance from the mortar surface. Steel rebars were embedded $20 \mathrm{~cm}$ from the bottom surface, in the mortar. Steel rebars were cleaned with acetone, distilled water and water from the supply network placed in the cube mortars. Each steel rebar was electrically conductive with copper wire to allow electrochemical measurements; the specimens were then partially immersed in $3.5 \mathrm{wt} \% \mathrm{NaCl}$ solution. The groups prepared in the lab were: 1) cement mortars with corrosion inhibitor used as an admixture in ratio $0.4 \mathrm{gr} / 100 \mathrm{gr}$ cement, 2) cement mortars with corrosion inhibitor sprayed on the external surface of the mortars, 3 ) cement mortars with organic coating containing corrosion inhibitor sprayed on the surface of mortar, 4) cement mortars with organic coating comprising inhibitor sprayed on the surface of the reinforcement before been inserted into the mortar and 5) cementmortars without corrosion inhibitors, for comparison reasons of the experimental results.

To evaluate the corrosion of steel rebars embedded in mortars were used the following methods:

- Half-cell potential measurements against time of exposure in chloride solution. An $\mathrm{Ag} / \mathrm{AgCl}$ electrode (was used as reference in contact with the surface of each specimen.

- Polarization Resistance (Rp) measurements using LPR method. Polarization curves recording of steel rebars.

- Calculation of Electrochemical mass loss using Faraday's Law.

- Gravimetric mass loss measurements of reinforcement steel against time of 
exposure in corrosive environment.

\subsection{Material Selecting}

For the construction of mortar specimens were used cement CEM II/B-M (P-W-L) $42.5 \mathrm{~N}$, calcareous fine aggregates $(0-4 \mathrm{~mm})$ and tap water of Athens. The water/cement/aggregate ratio is $0.5 / 1 / 3$ (or $245 \mathrm{Kg} / \mathrm{m}^{3}$ water, $489 \mathrm{Kg} / \mathrm{m}^{3}$ cement $/ 1466 \mathrm{Kg} / \mathrm{m}^{3}$ sand). The chemical composition of the cement is presented in Table 1 . The oxides are tested by XRF analysis and LOI values were tested according to ASTM D7348-13 "Standard Test Methods for Loss on Ignition (LOI) of Solid Combustion Residues". Cylindrical steel rebars type Tempcore B500C according to Greek specifications of Hellenic Organization for Standardization ELOT 142-37 [12] —with dimensions $100 \mathrm{~mm}$ height and $10 \mathrm{~mm}$ diameter were used. The chemical analysis of the steel reinforcement is tested by atomic absorption and is represented in Table 2. Figure 1 shows the reinforced mortars used in the present study.

- A corrosion inhibitor based on calcium nitrite $\left(\mathrm{Ca}\left(\mathrm{NO}_{2}\right)_{2}\right)$ was used as an admixture for the mass of concrete in proportion $4 \%$ by weight of cement and as a spray on the external surface of mortars.

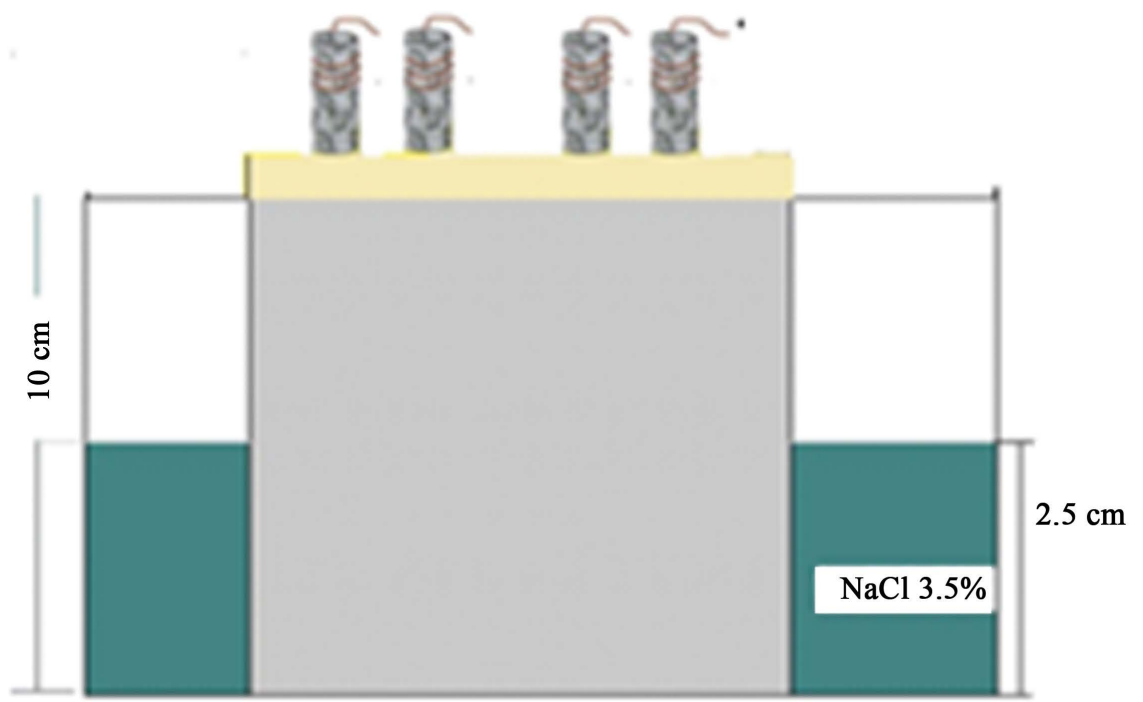

Figure 1. Schematic representation of the reinforced mortar specimen.

Table 1. Chemical composition of cement used for specimen's preparation.

\begin{tabular}{ccccccccccc}
\hline Oxides & $\mathrm{SiO}_{2}$ & $\mathrm{Al}_{2} \mathrm{O}$ & $\mathrm{Fe}_{2} \mathrm{O}_{3}$ & $\mathrm{CaO}$ & $\mathrm{MgO}$ & $\mathrm{K}_{2} \mathrm{O}$ & $\mathrm{NaO}$ & $\mathrm{SO}_{3}$ & $\mathrm{Cl}^{-}$ & LOI \\
\hline $\begin{array}{c}\text { CEM II } \\
\text { B-M 42.5N }\end{array}$ & 18.60 & 4.10 & 2.90 & 60.50 & 2.00 & 0.66 & 0.34 & 3.60 & 0.05 & $<8.50$ \\
\hline
\end{tabular}

Table 2. Chemical analysis of steel reinforcement steel.

\begin{tabular}{ccccccc}
\hline & $\mathrm{Fe}$ & $\mathrm{C}$ & $\mathrm{S}$ & $\mathrm{P}$ & $\mathrm{N}$ & $\mathrm{Ceq}$ \\
\hline B500C Tempcore & $99.168 \%$ & $0.22 \%$ & $0.05 \%$ & $0.05 \%$ & $0.012 \%$ & $0.5 \%$ \\
\hline
\end{tabular}


- The organic coating used included two coatings: a single-component (1K) varnish that contained the volatile corrosion inhibitor ( $\mathrm{VpCI}$ ) that vapor and permeate the concrete as a gas and through sorption form a passive film at the surface of reinforcing steel ( $1^{\text {st }}$ coating) and a single-component $(1 \mathrm{~K})$, varnish water-based that has high alkalinity, contains ingredients that can bind chlorides and prevents the entry of moisture into the concrete $\left(2^{\text {nd }}\right.$ coating). The second layer is applied after the first coating. Both varnishes were applied with brash at the dry surface of mortar or rebar (groups O.C.c and O.C.r Table 3).

\subsection{Specimens}

In order to evaluate the corrosion behavior of steel rebars in to cement mortar with corrosion inhibitors (additive or sprayed) or with varnishes were constructed. Five groups of specimens were constructed and each one of them consisted of 3 cube specimens formed in $100 \mathrm{~mm} \times 100 \mathrm{~mm}$. The ratio of the cement with aggregates and water were 1:3:0.5 and was added a $\mathrm{NaCl}$ solution of 5 $\mathrm{Kg} / \mathrm{m}^{3}$. Before insertion of steel rebars into the mortar were cleaned according to ISO/DIS 8407.3 and then weighted to $0.1 \mathrm{mg}$ accuracy. Then four (4) rebars for each specimen with a height of $H=100 \mathrm{~mm}$ and a diameter of $\varphi=50 \mathrm{~mm}$, embedded into the mortar, at equal distances from the center of the specimen. Each steel rebar was electrically conductive with copper wire to allow electrochemical measurements. After three (3) days the cement mortars were demolded and placed in suitable containers with water and thereafter remained for 28 days under laboratory conditions $\left(25^{\circ} \mathrm{C}\right.$ and $\left.50 \% \mathrm{RH}\right)$. At the end of the 28 days, the corrosion inhibitor was applied in each case, respectively.

Table 3 summarizes the five categories of specimens prepared for the experimental set-up.

\section{Experimental Set-Up}

\subsection{Half-Cell Potential Measurements (HCP)}

Half-cell potential measurements are the most widely used method of detection of corrosion of steel reinforcement in concrete [2]. The measurement of the

Table 3. Description of the five groups of cement mortars that were constructed.

\begin{tabular}{cl}
\hline Group C.I.s & $\begin{array}{l}\text { Specimens in which corrosion inhibitor was applied as a spray on the } \\
\text { external surface of mortar specimens }\end{array}$ \\
Group C.I.a & $\begin{array}{l}\text { Specimens in which corrosion inhibitor was used as an admixture for } \\
\text { the mass of concrete in with ratio } 0.4 \mathrm{gr} / 100 \mathrm{gr} \text { cement }\end{array}$ \\
Group O.C.c $\quad \begin{array}{l}\text { Specimens in which a two-layer organic coating that includes corrosion } \\
\text { inhibitor was applied on the external surface of mortar specimens }\end{array}$ \\
Group O.C.r $\quad \begin{array}{l}\text { Specimens in which a two-layer organic coating that includes corrosion } \\
\text { inhibitor was applied on the external surface of steel rebars } \\
\text { before been inserted into mortar }\end{array}$ \\
Group REF $\quad$\begin{tabular}{l} 
Reference specimens, without inhibitor application \\
\hline
\end{tabular}
\end{tabular}


corrosion potential of the steel using a reference electrode provides information on the corrosion rate (probability) embedder in cementitious materials [13].

The Half-cell potential (Ecorr) is a thermodynamically dimension and shows only the tendency of steel rebars for corrosion but does not give information for the corrosion rate of reinforcement. Corrosion rate of reinforcements is affected by a number of factors, which can be the diffusion of oxygen, the concrete's porosity and the presence of highly resistive layer [7]. Measurements of the electrochemical potential of the steel reinforcement were obtained with the use of a high-impedance voltammeter.

\subsection{Linear Polarization Resistance Technique (LPR)}

A Potensiostat/Galvanost at Model 263A from EG\&G Princeton Applied Research was used for the test with the associated software package in order to analyze the obtained data. The potential scan range was $\pm 10 \mathrm{mV}$ from OCP and the scan rate was $0.1 \mathrm{mV} / \mathrm{s}$. The experimental set-up (Figure 2) was consisted of the steel rebars that represent the working electrode, an electrode $\mathrm{Ag} / \mathrm{AgCl}$ which represents the reference electrode and a carbon bar as a counter electrode.

Linear Polarization Resistance Technique is a rapid and non-destructive electrochemical method of monitoring corrosion rate in real time. In LPR measurements the reinforcing steel is perturbed by a small amount of its equilibrium potential. The polarization resistance is measured by applying a potential of \pm 10 $\mathrm{mV}$ of the steel equilibrium potential at a rate of 0.1 milliliters per second while simultaneously measuring the current strength [11].

Based on Stern-Geary method, the polarization resistance is calculated using Equation (1).

$$
R_{p}=\frac{\Delta E}{\Delta I}
$$

$R_{p}$ values are highly correlated with a number of factors, such as surface treatment, corrosive environment and the materials that were used at the construction of the specimens [2].

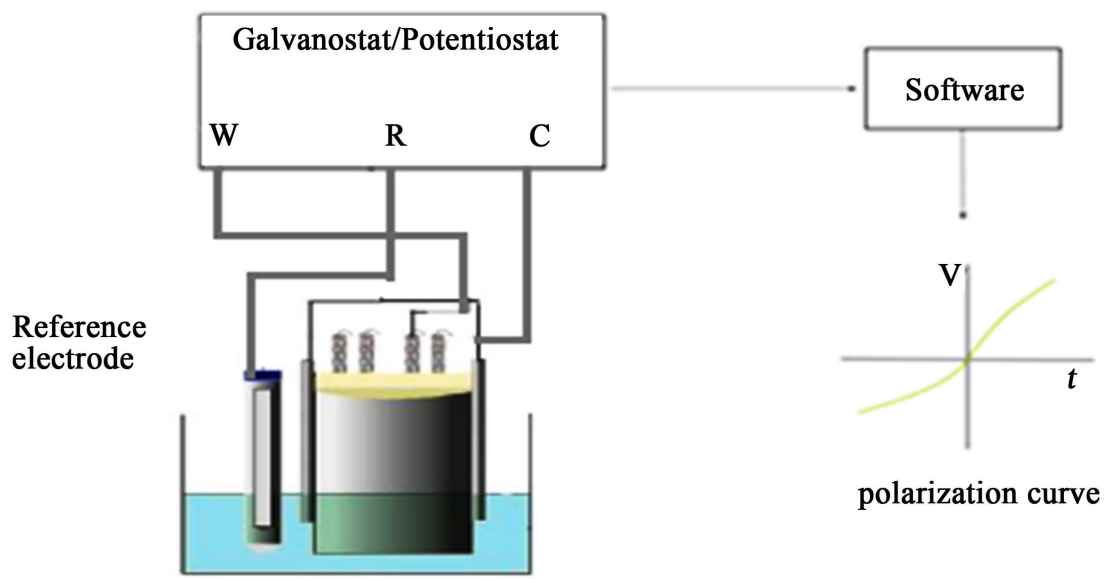

Figure 2. Experimental setup for polarization measurements. 
From Equation (1) can be calculated the corrosion rate $I_{\text {corr }}$ by the Equation (2):

$$
I_{\text {corr }}=\frac{\beta \alpha \cdot \beta c}{2.303(\beta \alpha+\beta c)}\left(\frac{1}{R_{p}}\right)
$$

where $\beta \alpha \cdot \beta c$ are the anodic and the cathodic Tafel slopes, respectively.

Corrosion current density, $i_{\text {corr }}$, is calculated by Equation (3), where $A$ is the surface area of steel that has been polarized.

$$
i_{\text {corr }}=\frac{I_{\text {corr }}}{A}
$$

The mass loss is calculated by the Equation (4)

$$
\beta=\frac{I * M * t}{z * F}
$$

where, $\beta$ is the mass loss of the steel rebar (g), $I$ is the corrosion rate (A), $M$ is the atomic mass of the metal (56 $\mathrm{g}$ for Fe), $t$ is the time of exposure (s), $z$ is the ion chance ( 2 for), and $F$ is the Faraday's constant $96.500\left(A^{*} s\right)$.

\subsection{Mass Loss of Steel Rebars}

Mortar specimens were broken at 12, 18 and 24 months, in order to evaluate the corrosion from chloride ions. After re-dusting and cleaning, the final weight of the steel was obtained and the mass loss was calculated from the difference between its initial and the final weight at any age:

$$
\Delta M=M_{\text {initial }}-M_{\text {final }}
$$

where, $M_{\text {initial }}$ is the mass of steel at the beginning, $M_{\text {final }}$ is the mass after immersion in $\mathrm{NaCl} 3.5 \% \mathrm{w} / \mathrm{t}$.

\section{Results and Discussion}

\subsection{Corrosion Evaluation}

\subsubsection{Half-Cell Potential Measurements}

Half-cell potential tests were conducted following the ASTM C-867 guidelines, in order to determine the likelihood of active corrosion. Half-cell potential difference was measured using a high-impedance voltammeter, between the working electrodes and a reference electrode of $\mathrm{Ag} / \mathrm{AgCl}$. Table 4 shows the corrosion condition for the steel's corrosion potential according to ASTM C-867 criteria [14]. Figure 3 presents the average values of corrosion potential versus time

Table 4. Corrosion potential and corrosion condition.

\begin{tabular}{cc}
\hline Steel's corrosion versus Silver/silver chloride/1.0 M KCl $(\mathrm{mV})$ & Corrosion condition \\
\hline$>-100$ & Low (10\% risk of corrosion) \\
-100 to -250 & Intermediate corrosion risk \\
$<-250$ & High (90\% risk of corrosion) \\
$<-400$ & Severe corrosion \\
\hline
\end{tabular}




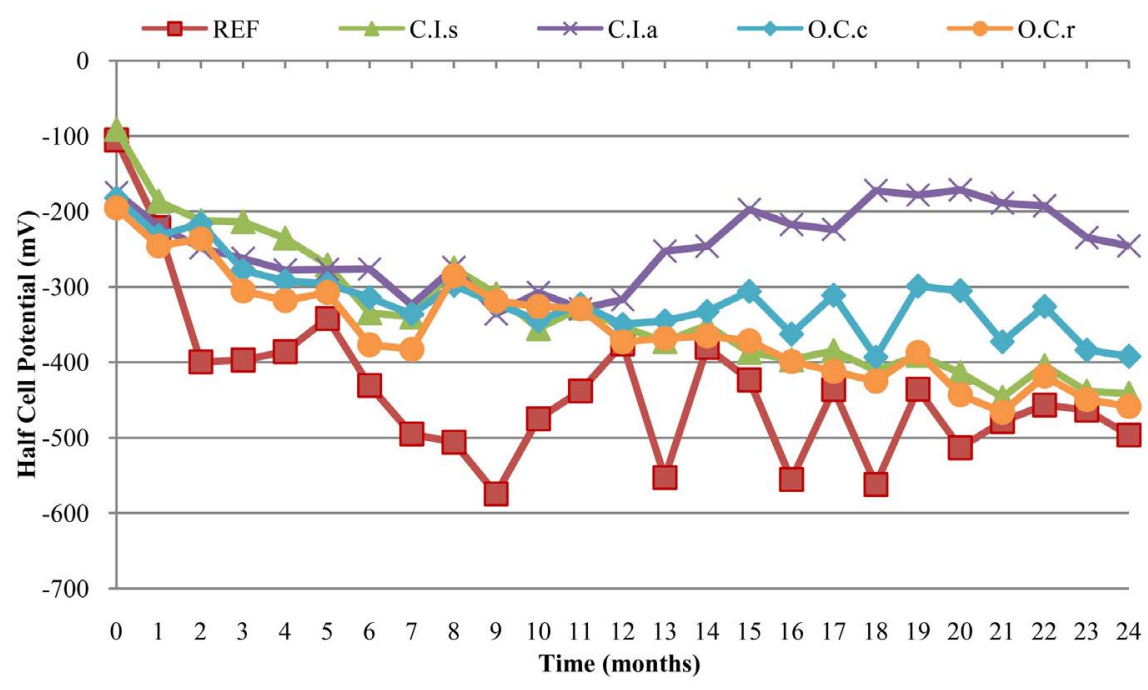

Figure 3. Half-Cell Potential versus time (months) of exposure in $\mathrm{NaCl}$ solution.

of exposure in $3.5 \mathrm{w} / \mathrm{t} \% \mathrm{NaCl}$ solution for all the groups of specimens. Half-cell potential was measured at the time that specimens were exposed to the corrosive environment ("zero" time) and every month for two years.

From the results, it can be seen that the potentials of all test groups over the longest residence time in the $3.5 \% \mathrm{NaCl}$ solution are between $-150 \mathrm{mV}$ and $-600 \mathrm{mV}$. According to ASTM C867 there is a high corrosion risk. The specimens which corrosion inhibitor has been added as an additive appear to exhibit more positive values than the other test groups (values -150 to $-400 \mathrm{mV}$ ). It is observed that the corrosion inhibitor that was used as an additive is activated after some time. A reason for that is likely to be that the additive corrosion inhibitor molecules are in a crystalline structure and released after a period of six months.

Also, the reference specimens appear to exhibit more electronegative values than the other groups. On the other hand, the specimens with organic coating on their surface exhibit more electropositive values than mortars with organic coating applied on the surface of steel rebars.

It should be mentioned that $E_{\text {corr }}$ values show the corrosion tendency of steel reinforcement. The actual corrosion from the chloride effect is shown by corrosion current measurements [15].

\subsubsection{Linear Polarization Resistance Measurements (LPR)}

Linear polarization measurements were performed to all the specimens every month for 24 months of exposing to the corrosion environment.

According to Table 5 [11] [16], after two years of exposure to the corrosive environment all specimens have a high risk to corrosion. It should be noted that Group C.I.a, in which corrosion inhibitor was added as an admixture into the concrete demonstrated better behavior from 12 months and then compared to the other protection systems. Additionally, REF and C.I.s groups exhibits lower values of Resistance between 2 to 20 months than the other batches. 
Table 5. Polarization resistance values and corresponding corrosion rate [11] [16].

\begin{tabular}{cc}
\hline$R_{p}\left(\mathrm{~K} \Omega \cdot \mathrm{cm}^{2}\right)$ & Corrosion rate \\
$>260$ & Passive condition \\
52 to 260 & Low to moderate corrosion \\
26 to 52 & Moderate to high corrosion \\
$<26$ & High corrosion rate \\
\hline
\end{tabular}

As an example, a curve from linear polarization measurements, from a specimen of Group C.I.a after 12 months in the corrosive environment, is presented in Figure 4.

In Figure 5 is presented polarization resistance $\left(R_{p}\right)$ of the groups of specimens versus the time they are exposing to the corrosion environment.

\subsubsection{Electrochemical Mass Loss}

The corrosion of steel rebars can be calculated using the Faraday's Law equation. Figure 6 illustrates the mass loss of steel for every groups of specimens up to 24 months of exposure in $\mathrm{NaCl}$ solution.

Generally, from Figure 6 the electrochemical mass loss increases with time for all groups. The electrochemical mass loss of the specimens that corrosion inhibitor is added as admixture in the mortar is lower than the electrochemical mass loss of the specimens that corrosion inhibitor was sprayed on the external surface of mortars. Figure 6 also shows that the reference specimens and the specimens that an organic coating was used either on the external surface or on the surface of the steel rebar show the highest electrochemical mass loss after 24 months in the corrosive environment.

From specimens that an organic coating was used, the smallest electrochemical loss presents the specimens where organic coating was applied on the surface of the mortar.

\subsubsection{Gravimetric Mass Loss Measurements}

For the calculation of the mass loss of the steel rebars, mortar specimens were partially immersed in $3.5 \mathrm{wt} \% \mathrm{NaCl}$ solution and broken after 12, 18 and 24 months. Figure 7 presents the mass loss of the steel rebars versus exposure time in the corrosion environment. From the results it can be observed that the mass loss of reinforcements increases over the time. The reference samples exhibit the highest mass loss values of the reinforcement after 12, 18 and 24 months in the corrosive environment. Furthermore, it is observed that specimens with the smallest mass loss are those in which the corrosion inhibitor has been added as a $4 \mathrm{w} / \mathrm{t} \%$ admixture.

Among specimens that a corrosion inhibitor was used, specimens containing $4 \mathrm{w} / \mathrm{t} \%$ corrosion inhibitor exhibits smaller mall loss than the specimens sprayed on their surface with corrosion inhibitor. Comparing the two groups in which an organic coating was used, it is observed that after 24 months the specimens in which the organic coating was applied on the external surface of the 


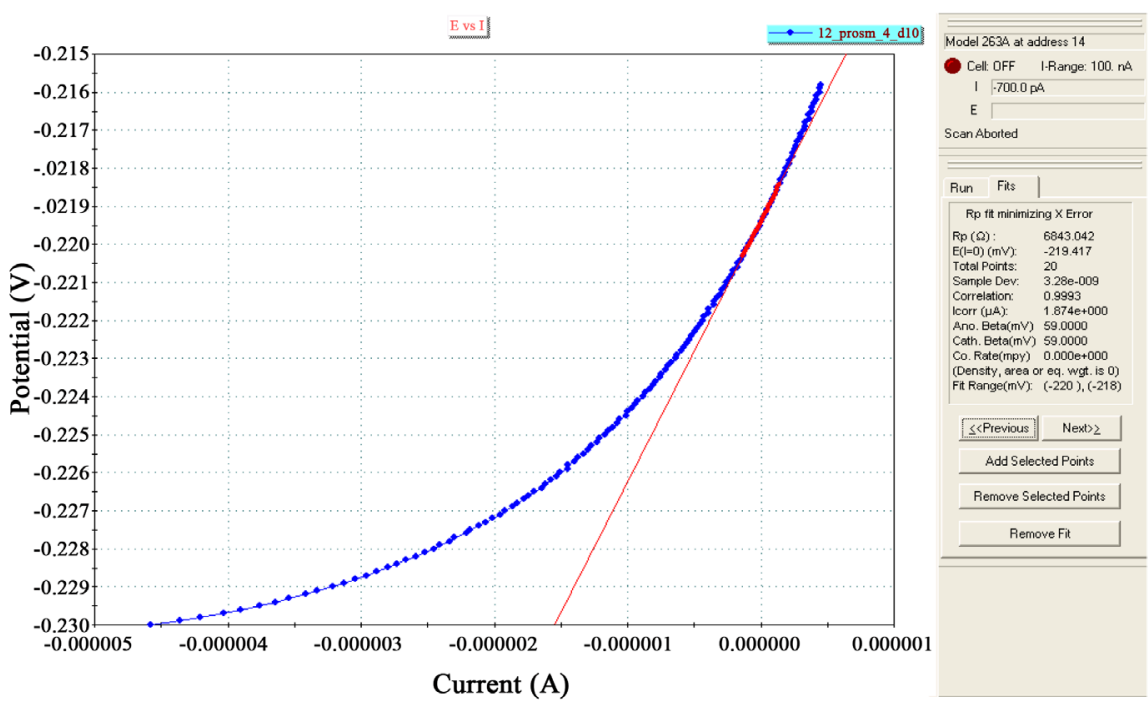

Figure 4. Linear polarization measurement, from a specimen of Group C.I.a after 12 months in the corrosive environment.

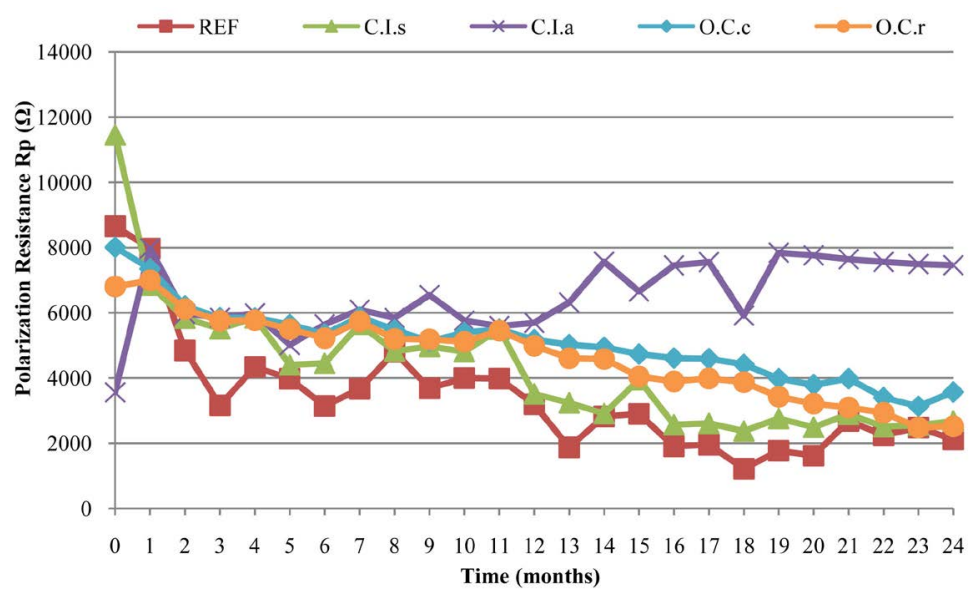

Figure 5. Polarization Resistance (Rp) versus time (months) of exposure in $\mathrm{NaCl}$ solution.

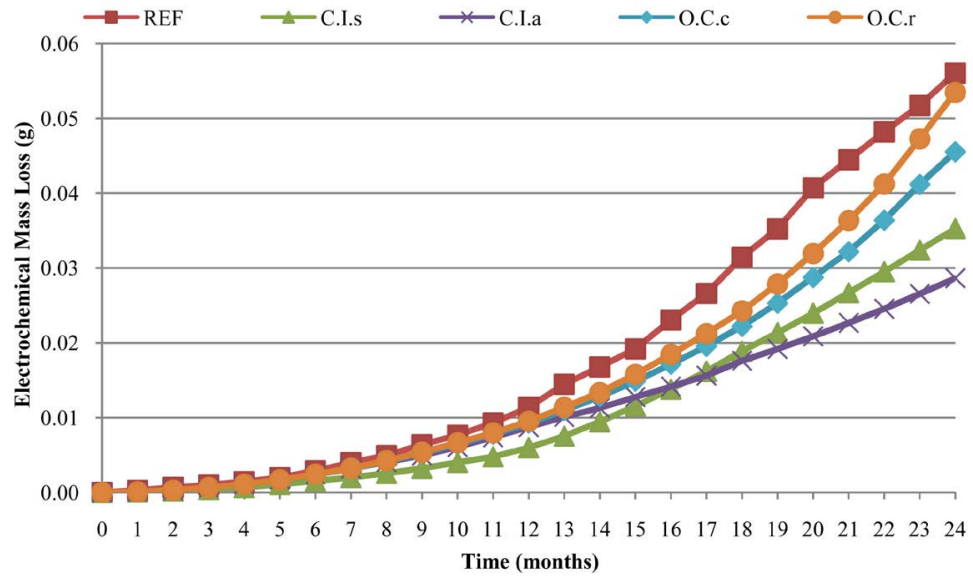

Figure 6. Electrochemical mass loss (g) versus Time (months) of exposure in $\mathrm{NaCl}$ solution. 


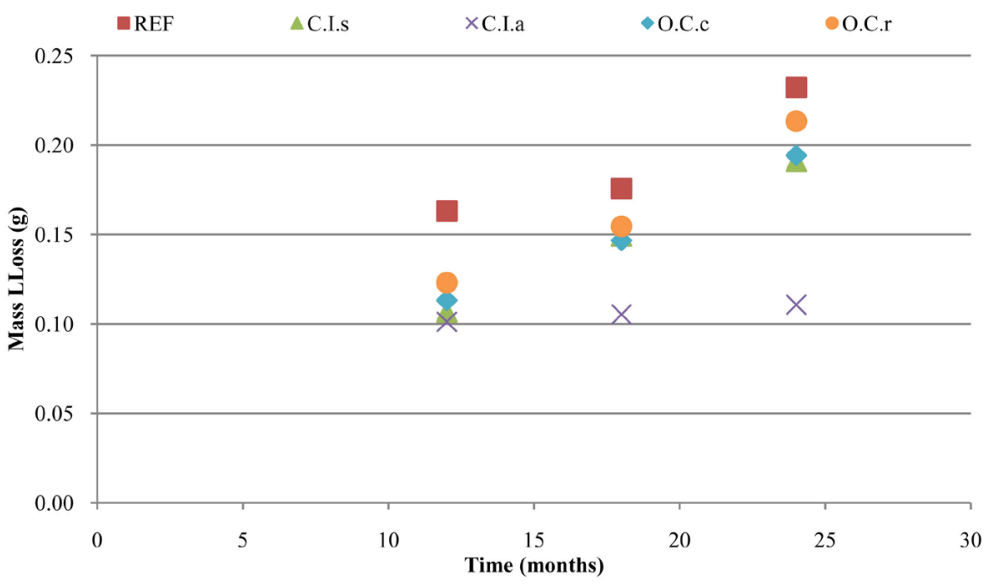

Figure 7. Mass loss (g) versus time (months) of exposure in $\mathrm{NaCl}$ solution.

mortar exhibit smaller mass loss that mortars where organic coating was applied on the surface of the steel rebars.

\section{Discussion}

From the evaluation methods used, it is observed that specimens in which corrosion inhibitor was used as an admixture for the mass of concrete in with ratio $0.4 \mathrm{gr} / 100 \mathrm{gr}$ cement had corroded less than the specimens with the other protective systems with a protection degree of $52 \%$ and $49 \%$ based to gravimetric and electrochemical mass loss, respectively. When corrosion inhibitor was used as a spray, the equal protection degree was $18 \%$ and $37 \%$.

For the specimens which the two-layer of organic coating has been applied to their surface, demonstrate higher protection degree (around 16\% gravimetric mass loss and 19\% electrochemical mass loss) of the specimens that the two-layer of organic coating has applied to the surface of the steel rebars. The degree of protection of a good corrosion inhibitor is generally estimated at $50 \%$. However, using the two varnishes the degree of protection was much smaller. This may be due to the diffusion of the volatile corrosion inhibitor not only into the mortar but also to the exterior surface of the specimen.

In previous work [17] the addition of organic corrosion inhibitors to mortar exposed in chlorine environment provided a protection rate of $25 \%$ based to mass loss. Another work [18] carried out the combined corrosion inhibitor protection with an inorganic coating in a chlorine environment. Protection rates in this case were only $21 \%$ (based to mass loss) for the corrosion inhibitor and $26 \%$ (based to mass loss) for combined use of corrosion inhibitor and inorganic coating. In the same work the use of acrylic water-based paint at the surface of mortar provided $39 \%$ protection degree.

Also, in a previous work [19] where it was examined the use of the same organic coating containing corrosion inhibitor that was used at the present study, in order to estimate anticorrosion protection on the reinforcement steel, showed that the use of the system organic coating/corrosion inhibitor applied on the 
surface of the mortar and on the surface of the steel rebar appeared an optimum anticorrosion protection of $29 \%$ based on mass loss, after 24 months in the corrosive environment, while the system organic coating/corrosion inhibitor applied on the surface of the mortar only gave a protection degree of $11 \%$ based on mass loss for the same period.

According to present study, although all the systems showed that protect from corrosion, the use of corrosion inhibitor based on calcium nitrite $\left(\mathrm{Ca}\left(\mathrm{NO}_{2}\right)_{2}\right)$, as an admixture in ratio of $4 \mathrm{wt} \%$ gave after 24 months exposing in corrosion environment a level of protection $52 \%$ (based on mass loss). However, when corrosion inhibitor was sprayed on the surface of the mortar, the maximum level of protection was $18 \%$ (based on mass loss).

Furthermore, the combined use of organic coating with volatile corrosion inhibitors in the organic coating on the surface of the mortar gave the maximum level of protection after 24 months $16 \%$.

When the corrosion inhibitor is applied by spraying, its entry into the mass of the mortar is accomplished by transferring water from the surface of the mortar to the interior. But this is reversible. When the surface of the mortar is wet (e.g. from rain), the corrosion inhibitor is removed away from the mortar. To prevent this transfer, the surface is painted.

In this work, the application of organic coating containing corrosion inhibitor was tested. In this way the two tasks: spray corrosion inhibitor and paint the surface, take place at the same time. This has the effect of reducing the cost of the repair. However, the specimens that the corrosion inhibitor was applied as spray (Group C.I.a. and Group C.I.s) behaved better than the specimens that was applied organic coating containing corrosion inhibitor (Groups O.C.c and O.C.r). Therefore, diffusion of more corrosion inhibitors predominates over the hindering caused by the organic coating.

Figure 8 shows the state of corrosion on steel reinforcement of Group REF and Group C.I.a. after 24 months. Images have taken as soon as specimens were
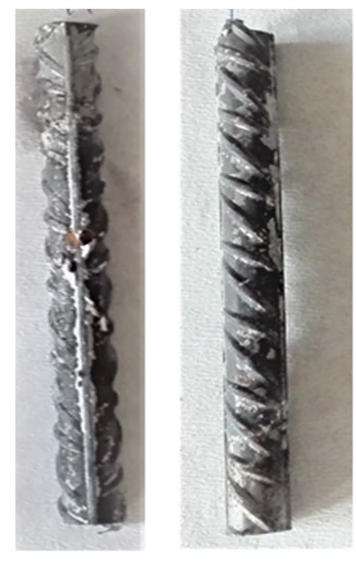

Group Ref

Group C.I.a

Figure 8. State of corrosion on steel reinforcement of Group REF and Group C.I.a. after 24 months. 
broken (before rebars were cleaned). As it is observed rebar from the Group that there was not a corrosion inhibitor application (REF) presents more extensive corrosion products on the surface of steel in comparison with rebar from Group C.I.a.

\section{Conclusions}

In the present paper, four systems were studied regarding their protection level against corrosion by chloride ions. From the results of the measurements the following can be drawn:

- Corrosion inhibitor that used as admixture into mortar provided better anticorrosion protection.

- Organic coating containing corrosion inhibitor provided better anticorrosion protection when the organic coating was applied on the external surface of the specimens (Group O.C.c) compared to specimens where organic coating was applied on the surface of steel reinforcement (Group O.C.r).

- Generally, all the systems used provided anticorrosion protection.

The optimization of the composition of the organic coating in order to protect against corrosion of concrete reinforcements could be further studied. A possible improvement of the second layer of the organic coating, would increase corrosion inhibitor in the concrete as the corrosion inhibitor contained in the first layer will not vapor outwards.

\section{Conflicts of Interest}

The authors declare no conflicts of interest regarding the publication of this paper.

\section{References}

[1] Song, H.-W. and Saraswathy, V. (2007) Corrosion Monitoring of Reinforced Concrete Structures-A Review. International Journal of Electrochemical Science, 2, $1-28$.

[2] Kouloumbi, N. and Batis, G. (1992) Chloride Corrosion of Steel Rebars in Mortars with Fly Ash Admixtures. Cement and Concrete Composites, 14, 199-207. https://doi.org/10.1016/0958-9465(92)90014-M

[3] Zacharopoulou, A., Zacharopoulou, E. and Batis, G. (2014) Protection Systems for Reinforced Concrete with Corrosion Inhibitors. Open Journal of Metal, 4, 86-92. https://doi.org/10.4236/ojmetal.2014.44010

[4] Hanson, C.M., Poursaee, A. and Jaffer, S.J. (2012) Corrosion of Reinforcing Bars in Concrete. The Masterbuilder, December 2012.

[5] Vyrides, I., Rakanta, E., Zafeiropoulou, T. and Batis, G. (2013) Efficiency of Amino Alcohols as Corrosion Inhibitors in Reinforced Concrtet. Open Journal of Civil Engineering, 3, 1-8. https://doi.org/10.4236/ojce.2013.32A001

[6] O’Reilly, M., Darwin, D., Browning, J., Xing, L., Lock Jr., C.E. and Virmani, Y.P. (2013) Effect of Corrosion Inhibitors on Concrete Pore Solution Composition and Corrosion Resistance. ACI Materials Journal, 110, 577-586.

[7] Chousidis, N., Rakanta, E., Ioannou, I. and Batis, G. (2015) Anticorrosive Effect of 
Electrochemical Manganese Dioxide By-Products in Reinforced Concrete. Journal of Materials Science and Chemical Engineering, 3, 9-20. https://doi.org/10.4236/msce.2015.35002

[8] Hanson, C.M., Mammoliti, L. and Hope, B.B. (1998) Corrosion Inhibitors in Concrete-Part I: The Principles. Cement and Concrete Research, 28, 1775-1781. https://doi.org/10.1016/S0008-8846(98)00142-2

[9] Valle-Moreno, A., Torres-Acosta, A., Martinez-Madrid, M. and Teran-Guilen, J. (2010) Efficiency of an Amine-Ester Based Corrosion Inhibitor for Concrete. Superficies y Vacio, 23, 188-192.

[10] Batis, G. and Rakanta, E. (2001) Effects of Migrating Corrosion Inhibitors on Reinforced Lightweight and Common Mortars. 2nd International Congress on Studies in Ancient Structures, Istanbul, Turkey, 9-13 July 2001, 560-570.

[11] Zafeiropoulou, T., Rakanta, E. and Batis, G. (2013) Carbonation Resistance and Anticorrosive Properties of Organic Coatings for Concrete Structures. Journal of Surface Engineered Materials and Advanced Technology, 3, 67-74. https://doi.org/10.4236/jsemat.2013.31A010

[12] ELOT 142-37, Hellenic Organization of Standardization, Athens.

[13] Broomfield, J.P. (2006) Corrosion of Steel in Concrete: Understanding, Investigation and Repair. 2nd Edition, Taylor \& Francis, Philadelphia, PA, 14.

[14] Broomfield, J.P. (2006) Corrosion of Steel in Concrete: Understanding, Investigation and Repair. 2nd Edition, Taylor \& Francis, Philadelphia, PA, 49.

[15] Chousidis, N., Rakanta, E., Ioannou, I. and Batis, G. (2016) Influence of Iron Mill scale Additive on the Physico-Mechanical Eproperties and Chloride Penetration Resistance of Concrete. Advances in Cement Research, 28, 389-402.

[16] American Society for Testing and Materials G59-97 (2009) Standard Test Method for Conducting Potentiodynamic Polarization Resistance Measurements. ASTM International, Philadelphia, PA.

[17] Batis, G., Routoulas, A. and Rakanta, E. (2003) Effects of Migrating Inhibitors on Corrosion of Reinforcing Steel Covered with Repair Mortar. Cement and Concrete Composites, 25, 109-115. https://doi.org/10.1016/S0958-9465(01)00047-6

[18] Batis, G., Pantazopoulou, P. and Routoulas, A. (2003) Corrosion Protection Investigation of Reinforcement by Inorganic Coating in the Presence of AlkanolamineBased Inhibitor. Cement and Concrete Composites, 25, 371-377. https://doi.org/10.1016/S0958-9465(02)00061-6

[19] Voulgari, E., Zacharopoulou, A., Chousidis, N. and Batis, G. (2019) Effect of Organic Coating Corrosion Inhibitor on Protection of Reinforced Mortar. Journal of Materials Science and Chemical Engineering, 7, 20-34.

https://doi.org/10.4236/msce.2019.71003 